\title{
Je třeba bránit společnost, která brání svobodu, aneb o transcendenci, veřejné sféře a aktivní hranici
}

\author{
Petr Drulák: Politika nezájmu: Česko a Západ v krizi \\ Praha, Sociologické nakladatelství (SLON) 2012, 323 s.
}

\begin{abstract}
We need a new concept of civil society as a civil sphere, a world of values and institutions that generates capacity for social criticism and democratic integration at the same time. Such a sphere relies on solidarity, on feelings for others whom we do not know but whom we respect out of principle, not experience, because of our persuasive commitment to a common secular faith.
\end{abstract}

Jeffrey Alexander [2006: 4]

Knihu Petra Druláka [2012] čtu jako svého druhu filosoficko-teologické pojednání. Převažují v ní normativní tóny, což rozhodně nepovažuji za diskvalifikující. Její ambiciózní a široce rozkročená interpretační základna sice vede nutně ke značnému redukcionismu, ale i přesto $\mathrm{v}$ textu nacházím množství více či méně inspirativních interpretací, z nichž si v následujícím textu vyberu dvě. Omezený prostor diskusního příspěvku tak jako tak nedovoluje formulovat smysluplnou reakci ke všemu, co mne v textu inspirovalo ke kritice.

Po terminologické reinterpretaci, která vyšla vstříc mým potřebám a dispozicím, ${ }^{1}$ musím konstatovat, že plně sdílím autorův apel na nutnost nově promýš-

\footnotetext{
${ }^{1}$ Po přečtení textu jsem došel k závěru, že pro čtenáře zatíženého instrumentáriem sociálněvědního bádání může jistou bariéru v porozumění textu představovat (z mého pohledu matoucí) filosoficko-teologická rozvolněnost pojmů. To neznamená, že autor důsledně nevymezuje obsah jím užívaných pojmů. Ba naopak, pokud jsem četl pozorně, činí tak snad u všech významných pojmů. Přesto se musím přiznat, že při opakovaném čtení jsem textu dokázal produktivněji porozumět tehdy, když jsem začal za některé autorem užívané pojmy dosazovat pojmy vlastní. Pojem bratrství jsem v návaznosti na kontext nahrazoval pojmy solidarita, respekt či sociální soudržnost, pojem láska pojmy diověry (autor sám užívá na některých místech pojmy láska a di̊věra zástupně, především na s. 34) či víry, pojem pospolitost pojmy politický útvar či politické společenství, pojem obdarovávat jsem nahrazoval zejména pojmem respektovat či omezovat se a pojem dar jsem v závislosti na kontextu interpretoval jako závazek, sebeomezení či zdanění. Pojem nezájem, který snad jediný podle mne není autorem dostatečně koncepčně uchopen, jsem nahrazoval pojmy apatie, pasivita, sebestřednost či sobectví a pojem mystika, který autor opakovaně užívá ve vztahu k transcendentnímu zakotvení společnosti, jsem nahrazoval (opět v závislosti na kontextu) pojmy posvátnost, esence či transcendence. Možná se z mé strany jedná o zbytečný terminologický pedantismus, ačkoli si to nemyslím. Jakožto sociální badatel, který je ovlivněn mimo jiné
}

(C) Sociologický ústav AV ČR, v.v.i., Praha 2015 
let vztah mezi svobodou, rovností a solidaritou. Sdílím také celou řadu věcnými argumenty podložených morálních a politických aspirací, které v textu zaznívají, především potřebu formovat přeshraniční evropskou solidaritu i přeshraniční demokraticky ustavenou politickou vưli. Ve svém příspěvku bych se omezil na rozvedení z mého pohledu dvou hlavních a vzájemně propojených momentů: (1) Jednak je to opakovaný odkaz na mystické založení společnosti a z toho vycházející implicitní požadavek desekularizace veřejné sféry. Tento požadavek bych se pokusil argumentačně prohloubit a kriticky rozvést. V návaznosti na tento moment bych (2) chtěl rozvést požadavek evropské (či globální) solidarity a otázku toho, jakým způsobem můžeme odstraňovat překážky v konstruování přeshraničních zájmů, demokratické politické vůle a solidarity. Propojenost obou momentů je klíčová a ve svém př́spěvku budu argumentovat ve prospěch teze, že podmínkou zachování veřejné sféry na evropském Západě je zajištování sekulárního rázu veřejné sféry, která je výrazem individualistického mysticismu, a který má pro sekulární povahu veřejné sféry (a udržitelnost liberální demokracie) konstitutivní význam. Na základě tohoto požadavku chci dále argumentovat ve prospěch tvrzení, že klíčovým předpokladem posilování přeshraniční (evropské) solidarity je institucionální zajištování a kulturní obsluhování aktioní hranice, které je podmínkou formování přeshraniční politické vůle, transnacionalizace suverenity lidu i veřejné sféry, což umožní formování evropských identit založených na nenásilném, či dokonce kooperativním střetávání s jinými.

Předně musím předeslat, že shledávám obtížným uvažovat o Západu ve vztahu $\mathrm{k}$ fenoménu krize $\mathrm{v}$ singuláru. Západ představuje značně heteronomní sociální kontext, kde existují velmi rozdílné náboženské, kulturní a institucionální předpoklady a také různé úrovně ekonomické vyspělosti, institucionální efektivity i kvality demokratického vládnutí. Např́íklad ve Švýcarsku či v mnoha anglosaských i kontinentálních zemích to přiliš krizově nevypadá, pokud krizí míníme civilizační propad týkající se kulturních, politických i ekonomických aspektů každodenního života většiny obyvatel. Navíc při důkladném promýšlení demokratického vládnutí můžeme dojít k závěru, tak jako mnoho sociálních badatelů, že krize je vlastně imanentním rysem demokracie a "situation normal“, nebot' na rozdíl od jiných způsobů vládnutí demokratický režim dokáže zvládat - ve svobodné společnosti nevyhnutelnou - proměnlivost sociálních konfliktů a problémů bez větších politických a sociálních otřesů, či dokonce revolucí. Přijetí konfliktnosti jako „přirozeného řádu věcí" se však neobejde bez jisté horečnatosti a neklidu (jak by to formuloval Tocqueville), stejně tak se neobejde bez slepých

strukturalismem (a obratem k jazyku) připouštím možnost, že výrazové formy strukturují naše vnímání reality, naše jednání a tím i realitu samu. Největší metodologický problém jsem měl s pojmem bratrstoí, nebot' odkazuje na rodinný sourozenecký vztah a navíc je genderově zatížen. Nedomnívám se, že by si autor nebyl tohoto etymologického zatížení vědom, ale zřejmě je nepovažuje za vážnější metodologický problém. Ve svém příspěvku budu také užívat výše předložené pojmy, které (pravděpodobně) představují obsahové (přinejmenším částečně se překrývající) ekvivalenty k pojmům, které užívá Petr Drulák. 
uliček a více či méně nepříjemných zkušeností a přešlapů. Bylo by možné argumentovat i tak, že Evropa si udržuje stabilitu pouze skrze transformační dynamiku a že evropské pojetí řádu se opírá o zvládání sociálních změn pomocí civilizování politické moci skrze právní a institucionální inovace.

Nicméně je podle mne možné formulovat opatrnou obavu, že evropský Západ jako celek přece jenom vykazuje jisté známky krize. I přes značnou různorodost Západu je možné v naprosté většině evropských zemí spatřovat problémy související především se střetáváním a potýkáním se s jinakostí. Tato latentní krize má četné příčiny a důsledky (na jejichž rozbor zde není prostor), ale jejím nejviditelnějším projevem je nárůst xenofobie, posilování nacionalismu a oslabování pozice etablovaných středových politických stran. $\mathrm{V}$ důsledku těchto posunů dochází také $\mathrm{k}$ postupnému prosazování neliberálních požadavků, politik i veřejné rétoriky do politického mainstreamu. Pokud bych měl ve vztahu $\mathrm{k}$ takto pojatému fenoménu krize formulovat politický apel či morální proklamaci, navrhoval bych především požadavek bránit společnost, která brání svobodu. Svoboda a individuální autonomie předpokládá nejen právní rovnost, ale také rovnost příležitostí i sociální soudržnost. Řád v Evropě je založen na osvícenských idejích svobody a autonomie jedince. Svoboda však často vede k nespravedlnostem a má tendenci oslabovat sociální soudržnost, což je nutno zvládat a vyrovnávat pomocí institucionálních inovací, institucionální reflexivity a veřejného učení. Bez veřejného učení není možné bránit sociální soudržnost pomocí odstraňování skrytých forem znevýhodňování a sociálního vylučování. Ve své diagnóze krize bych tedy kladl důraz nejen na formy posilování sociální soudržnosti, ale také na význam inovativnosti a reflexivity institucí, veřejného učení (včetně politické socializace) a především na obhajobu sekulární povahy veřejné sféry.

\section{Společnost a transcendence}

Domnívám se, že text Petra Druláka vychází z předpokladu societálního esencialismu. Autor v textu opakovaně odkazuje k mystickému založení politického společenství. Kniha chce být obrannou liberálního dědictví [Drulák 2012: 13] a reflektuje také „zamlčené mystické kořeny liberalismu“ [ibid.: 33], avšak pojetí (veřejného) zájmu, které kniha předkládá, váhavě kolísá mezi liberalismem a autoritářstvím. Autor odmítá (pouhé) sekulární založení společnosti pomocí vlády práva (a smlouvy), jež je konstituována jednáním svých členů a institucí. Z autorovy argumentace mi však není zcela jasné, jak zajistíme racionalizační logiku práva, která je zaručena sekulární povahou veřejné sféry a která umožňuje civilizování politické moci. Autor si je vědom nebezpečí, které vyplývá z propojení politiky a mystiky [ibid.: 32]. Jeho sugestivní argumentace na mne však dělá dojem, že transcendentní zakotvení společnosti chápe také jako jeden z konstitutivních prvků sociálního řádu. „Pospolitost se bez mystiky neobejde“, píše autor [ibid.: 33] a liberalismu vytýká, že mystiku vykazuje z veřejné sféry do sféry soukromé. Ačkoli si je vědom rizika posvěcení sociálního řádu a politické moci, nenacházím 
v jeho argumentaci dostatečné pojistky, které by dokázaly bránit trendu desekularizace veřejné sféry.

Podobně jako mnozí autoři (Ulrich Beck, Charles Taylor, Jürgen Habermas), kteří se zabývají sociologií transcendence či náboženství, považuji požadavek sekularizace veřejné sféry za konstitutivní princip liberální demokracie, a to především proto, že umožňuje institucionalizaci dělby moci, kritiky a existenci politické opozice. Pokud je obec/pospolitost výrazem transcendence a její sdílená kultura je konstituována kódem posvátnosti, jak zabráníme tomu, aby se tato transcendentní normativita nestala legitimizačním principem politické moci, a jak ošetříme v konfrontaci se sakrální aurou sociálního řádu (a institucionální moci) prostor osobní autonomie a právo na kritiku? Jak zajistíme, aby (kritická) opozice nebyla vnímána jako hluboký narušitel sociálního řádu? I jen zvěcnění či institucionalizace kategorie obecného blaha (zájmu) v sobě skrývá nebezpečí viktimizace opozice jako společenského nepřítele. Logickým důsledkem ideologie a rétoriky "obecného blaha" v silném slova smyslu je úvaha, že všechna opozice stojí proti němu a je proto nezákonná. Pokud pro občanské aspirace vyčleníme jako jedinou volbu „kultivaci zahrádky“, mohli bychom se stát advokáty nové verze epikurejské morality. Pojem občanský je v tomto pojetí rezervován pro význam pečující o obecné blaho. Termín občanské společnosti opravdu bývá díky svému silnému morálnímu akcentu někdy chápán v moderní sociologii jako synonymum pro označení morálně založené pospolitosti (Gemeinschaft), jež stojí proti formálně založené společnosti (Gesellschaft) a amorálnímu státu. Idea moderního občanství je však v tomto pojetí nebezpečně okleštěna.

V této souvislosti se nabízí celá řada dalších otázek. Především, jak zabráníme splynutí morálky a politiky (a práva), jejichž diferenciace je základem moderní liberální demokracie? A zejména, proč by potřebu transcendence měla naplňovat společnost, obec, či dokonce politický řád (polity)? Sociální soudržnost by podle Petra Druláka měla být odvozena od nových příběhů (narací či ideologií), které podle něj musí bít inkluzivní a tolerantní. S tím nelze než souhlasit. Avšak pokud je bratrství vymezené křestanskou láskou [ibid.: 28], jakou roli budou v evropské společnosti hrát nekřestané a jiné subkultury, které nesdílí dominantní naraci? Jak chceme zvládat střetávání světových náboženství na evropském Západě, pokud konstituujeme veřejnou sféru na dominanci jedné monoteistické víry? Opravdu chceme tyto subkultury „ponechat [...] soukromým cílům” a eventuálně jim nabízet „příležitost tento postoj přehodnotit“ [ibid.: 292]? Jak však zabráníme jejich viktimizaci a exkluzi v př́ípadě, že veřejnou sféru ovládne narace a představa societální transcendence, kterým jejich víra, jejich narace a jejich zájmy odporují? Nebo by spíše měly mít tyto subkultury také právo a príležitost prosazovat své zájmy jako legitimní, či dokonce veřejně prospěšné? Osobně se domnívám, že ano. To ovšem předpokládá zajištění jednotného diskursivního prostoru, ve kterém se mohou představitelé pluralitních narací stýkat jako rovnocenní partneři. Pokud však označíme nějakou transcendentní naraci či ideologii za konstitutivní prvek celého sociálního řádu, jak bude možné udržet 
veřejnou sféru, která by byla otevřená všem občanům, zájmům či naracím a která by zajištovala rovný přístup i status všech účastníků diskuse? K otázce sdíleného diskursivního prostoru se vrátíme později.

\section{Individualistický mysticismus}

Potřebu i vědomí transcendence je jistě možno a záhodno vnášet do veřejné sféry, není však možno veřejnou sféru tímto vědomím konstituovat. Náboženství si musí být takříkajíc vědomo svých limitů a tyto limity na sebe musí uvalit. Především pokud jde o konstituci institucionálního politického rámce, a právního státu (vlády práva), není možné aplikovat stejné metody, které se uplatňují $\mathrm{v}$ náboženství. Kritiku liberalismu pro jeho vytlačení mysticismu $\mathrm{z}$ veřejné sféry, jež předkládá Petr Drulák, je možno interpretovat různě v závislosti na pojetí mysticismu. Liberálně založená veřejná sféra chce především obsluhovat hodnoty individuální svobody a lidské důstojnosti. Tyto hodnoty, které jsou zakotveny a s posvátnou úctou re/produkovány ve veřejné sféře, jsou založeny na nenásilí a na individualistickém mysticismu. Liberální demokracie se vzdává mysticismu pospolitosti ve prospěch úcty $\mathrm{k}$ individuální existenci a věří $\mathrm{v}$ to, že individualistický mysticismu by měl prostupovat veřejnou sférou a v optimálním př́ípadě ji plně opanovat. To se projevuje především oddaností mnohých Evropanů k lidským právům. Domnívám se proto, že societární mysticismus, který Petr Drulák interpretuje jako př́padnou formu posilování sociální soudržnosti, je třeba odmítnout ve prospěch individualistického mysticismu, který může sloužit stejnému účelu, ačkoliv se vyznačuje - v jistém smyslu - vyšší mírou abstrakce či universalismu. Jeho prožívání znesnadňuje konstruování ,jiného“ jako konstitutivního prvku (kolektivní) identity. Individualizovaný mysticismus není výrazem nějakého solipsismu, nýbrž jde spíše o vztahovou kategorii. Jednu z nejpřesvědčivějších obhajob individualizovaného mysticismu nacházíme v díle Emmanuela Lévinase [1994], který interpretuje setkání s druhým/jiným jako jedinečnou a fundamentální událost, která zakládá vztah odpovědnosti za konkrétního druhého/jiného. Vztah odpovědnosti za druhého/jiného představuje základní a nejvyšší projev lidství. Odpovědnost za jiného předchází podle Lévinase svobodě a představuje vlastně cestu k bohu. Každý člověk byl stvořen k obrazu božímu. Lidská identita (a subjektivita) je v Levinasově pojetí konstituována až teprve přijetím odpovědnosti za druhého, za jinakost, díky čemuž konstituuji (nalézám) sám sebe. Toto je nesmírně silný normativní morální moment, který především v promýšlení evropeizace (transformace) kolektivních identit (v Evropě) významně rezonuje. Civilizované střetávání s jinakostí - nikoli její konstruování - musí být podstatnou součástí formování kolektivních identit v Evropě.

Podmínky globalizované modernity jsou navíc zřejmým empirickým ospravedlněním tohoto požadavku. Každý, kdo se obával nástupu sekulární konzumní monokultury, si dnes může s úlevou vydechnout. Pád sekulárního universalismu dnes představuje podstatně větší riziko. Především díky svým rozkladným 
důsledkům na racionalizační základ veřejné sféry jakožto hlavního organizačního principu svobodné společnosti, který by zajištoval vládu práva, individuální autonomii a slušné (civil) vládnutí [Beck 2010: 44]. Otázky desekularizace (či postsekularizace) Západu dnes zaměstnávají mnohé významné sociální badatele a v tomto ohledu je možné př́ispěvek Petra Druláka vítat jako snahu o originální př́spěvek $\mathrm{k}$ této diskusi. Sociologické interpretace náboženských předpokladů sociálního řádu, které všechny vycházejí z klasiků sociologie náboženství Webera a Durkheima, jsou však většinou zasazeny do širšího kontextu teorie modernity. Historická afinita mezi modernizací a sekularizací představuje jeden $\mathrm{z}$ ústředních předsudků modernizačních a sekularizačních teorií, a jak podle mne správně argumentuje Ulrich Beck [2010: 21], zhroucení sekularizační teorie neznamená a nemůže znamenat návrat societálnúho mysticismu do veřejné sféry, znamená spíše konec západního monopolu modernity.

Konec singuláru modernity znamená podle Becka [2010: 44] také konec singuláru sekularity. Paradoxním důsledkem vytlačení náboženství a mysticismu $\mathrm{z}$ veřejné sféry je především objevení nové dimenze lidské spirituality. Osvobození náboženství od světské moci církve přináší zduchovění či spiritualizaci náboženství a skutečnost, že náboženství vyklidilo pole odpovědnosti za racionální vědění (ve prospěch vědy a státu), je možné podle Becka [2010: 24-25] interpretovat především jako "great gain for religion“, či dokonce jako boží dar. Sekularizací je náboženství donuceno nebýt ničím jiným než právě náboženstvím, jehož úkolem je starat se o jedinečnou lidskou existenci a oslavovat její spiritualitu. Sekularizace dláždila cestu revitalizaci náboženství a církve se musí vyhnout rizi$\mathrm{ku}$, že se z nich stanou čistě profánní instituce. Jak ukazují výzkumy, individualizace religiozity jde ruku $v$ ruce s poklesem organizované religiozity ve veřejné sféře [Beck 2010: 40]. To ještě neznamená, že spiritualita a náboženské argumenty nemohou a nesmí hrát ve veřejné sféře žádnou roli, ba naopak. Náboženské argumenty se mohou úspěšně uplatňovat $\mathrm{v}$ situaci, kdy racionální deliberace odhaluje vážné trhliny a nedostatky v argumentaci a naráží tak na své meze [March 2013]. Jde o známý argument, který snad nejpřesvědčivěji formuloval Kant: pokud království rozumu padá pod tíhou rozumu samého, není snad ani dost dobře možné morální a náboženské argumenty ve veřejné diskusi neuplatňovat. Náboženské argumenty však nemohou představovat konstitutivní metodu utváření práva, formování politických institucí a organizací [Beck 2010: 26].

\section{Evropeizace jako střetávání s jinými}

Především si však musíme klást otázku, jak můžeme zvládat střetávání světových náboženství (tedy střetávání s jinými), která nejsou v době globalizované modernity teritoriálně vymezena. Tím se dostáváme k druhému momentu, který mne při četbě textu inspiroval, a tím je požadavek přeshraniční transnacionální (i transnáboženské) solidarity. Tento požadavek má především pro politicky fragmentovanou Evropu zcela zásadní význam, neboť rozšîření demokratických 
procedur přes hranice národního státu se $\mathrm{v}$ současnosti jeví jako politická nezbytnost. Nelze než souhlasit s argumentem, že velký politický systém je v podmínkách globalizované modernity demokratičtější než malý, protože má větší kapacitu vypořádat se s problémy svých občanů, jakými jsou ochrana trhu, ovzduší či zajištění bezpečí [Habermas 2013]. Požadavek transnacionalizace demokracie je především požadavkem transnacionalizace suverenity lidu. Je však zřejmé, že transnacionalizace suverenity lidu, což je substanciální kategorie liberální demokracie, není možná bez transnacionalizace veřejné sféry i kolektivních identit. Významným krokem k demokratizaci EU je Lisabonská smlouva a požadavek transnacionalizace suverenity lidu se uplatňuje především v principu tzv. sdílené suverenity. Ústavodárnými subjekty EU jsou jak občané EU, tak občané jednotlivých členských států (nikoli státy, jak se někdy mylně interpretuje). Subjektem legitimity EU jsou jedině individuální občané, kteří jsou občany Unie i členského státu, tedy ti samí občané, kteří působí na dvou legitimizačních kolejích, tomu také odpovídá dělba moci, jakkoli nedokonalá, mezi Radou a Parlamentem EU [Habermas 2013: 72].

Požadavek transnacionalizace solidarity i suverenity lidu je dnes spojován především s evropeizací veřejné sféry či veřejných sfér v Evropě, tedy jak s posilováním rámce nadnárodní komunikace, tak se vzájemnou provázaností a prostupností již existujících veřejných sfér a diskursů. Tato provázanost mimo jiné nepochybně posiluje také transnacionalizaci kolektivních identit [Müller 2008, 2012]. Evropská společnost (stejně jako jakákoli jiná moderní sekularizovaná společnost) je dnes představitelná především jako komunita komunikace [Risse 2010]. Předpokladem evropské společnosti jakožto komunity komunikace je však obsluhování aktivních hranic mezi fragmentovanými veřejnými sférami, jež budou garantovat a obsluhovat společný diskursivní prostor, který nebude konstituován polarizujícím vymezováním my/oni, nýbrž bude vnímat aktéry „zpoza“ hranice jako legitimní partnery do diskuse, jako někoho, kdo může být jiný i stejný zároveň. Evropská veřejná sféra, jakožto sdílený prostor komunikace, by měla být prostředím, kde dochází k odlišování, které implikuje nejrůznější formy kulturní konvergence [více viz např. Delanty 2011], spíše než k vymezování, které implikuje polarizaci. Odlišování je vždy otevřeným výsledkem komunikace a prosazování vlastní kompetence, vymezování naopak jejich stereo/typizovaným apriorním předpokladem.

Předpokladem aktiuní hranice jsou jednak specifičtí aktéři a kanály komunikace a jednak kompatibilita vnějších podmínek na obou stranách hranice [Müller 2014]. Vnější podmínky, mezi které je možné počítat kulturní zdroje a infrastrukturu, musí zaručovat smysluplnou výměnu informací a šíření argumentů a vědění oběma směry hranice. Existence aktiuní hranice je také závislá na určitých institucionálních oporách (např. NGO, přeshraniční komunikační fóra, přeshraniční poskytování veřejných služeb, jakými jsou lékařská péče či před/školní vzdělávání, studentské výměny, přeshraniční granty a vládní programy, přeshraniční média aj.), které umožňují obsluhování hranice jako otevřené institucionální 
struktury [Koopmans 2007] a které usnadňují střetávání a komunikaci rozdílnosti mezi aktéry z obou stran hranice. Aktivní hranice je jedním z výrazů takového pojetí kosmopolitismu, který staví na pěstování univerzální kultury pravidel dialogu [Delanty 2011] a na překonávání pasioních hranic. Mezi ty nejvážnější důsledky pasioní hranice patří sociální vylučování, ignorance, diskriminace a v nejzazších př́ípadech násilí. Pluralita názorů nemůže vylučovat smysluplný dialog ani možnost vzájemného hodnocení. Tato kosmopolitní orientace nehledá - jak předpokládají mnozí kritici kosmopolitismu - homogenní globální kulturu či diverzitu pro diverzitu, nýbrž prostor k veřejnému učení, pro svobodnou sociokulturní změnu i pro otevřenou re/konstrukci identit.

Komunikace různosti, která je konstituována ochotou a připraveností sdílet rozdílné narace a historické i morální interpretace, předpokládá, rozvijí i obohacuje společný komunikační prostor [Eder 2006]. Skrze nalézání a obsluhování tohoto sdíleného diskursivního prostoru mohou být aktivní hranice zdrojem formování pozitivních identit, které jsou založeny na kompetenci a integritě a produkují uspokojení. Sdílený komunikační prostor může být jak zdrojem pocitu odlišné svébytnosti (identity), tak zdrojem snášenlivosti vůči jinému, které však není vnímáno jako nebezpečné, ale pouze jako jiné (dosud málo známé), které však umím a chci poznávat. Schopnost odlišit ,jiné“ od nebezpečného a reflektivně nalézat i přehodnocovat meze naší tolerance (jakožto snášenlivosti vưči jinému, které není nebezpečné) představuje v liberálních demokraciích jistý druh občanské kompetence, který posiluje rozvoj kompetencí jiného typu (profesní, sociální i personální), čímž napomáhá formování již zmíněných pozitivních identit. Aktivní hranice tedy předpokládá a rozvijí to, co bývá sociology nazýváno jako občanský (civil) kód kolektivní identity [Shils 1975], stejně tak nabízí nejpříznivější předpoklady pro vytváření podmínek vhodných ke konstrukci pozitivních identit. Pozitivní identity zpětně vytvářejí nejpříznivější podmínky ke komplementaritě kolektivních identit, a tedy k posilování sociální soudržnosti, což nás však vzhledem $k$ jejich vazbě na obsluhování aktivní hranice a ke konstrukci občanského (civil) kódu kolektivní identity nemůže př́liš překvapit. Souhrnně řečeno, mezi aktivní hranicí, občanským kódem kolektivní identity a pozitivní identitou zřejmě existují reflexivní vazby a resonance, které pracují jak ve prospěch sociální plurality a otevřenosti vůči kritice (a veřejnému učení), tak ve prospěch sociálního začleňování a solidarity.

\section{Závěrem}

Souhlasím s Petrem Drulákem v tom, že je třeba bránit společnost (Foucault), ale nejsem si jist tím, zda bychom to měli dělat především vzýváním či odkazy na mystické založení společnosti. Cestu vidím spíše $v$ ochraně veřejnosti ( $v$ silném slova smyslu), která je jak zárukou ochrany individuální autonomie, lidských práv a dưstojnosti, tak zárukou férového nalézání (či konstruování) společných zájmů. Skutečnost, že mnohé liberální demokracie nejsou sto společnost 
chránit, nevidím jako důvod $\mathrm{k}$ tomu, abychom posilovali vědomí iracionálního, transcendentního a ve své podstatně nábožensky založeného pojetí společnosti. Nelze nesouhlasit s tím, že mnohé liberální společnosti nejsou schopny dostatečně mobilizovat občanskou solidaritu a kapacitu k dobrovolnému sebe/omezení, či dokonce obětování. Východisko však vidím spíše v demokratizaci rodiny, ve veřejném učení, v každodenní ochraně veřejnosti před rozkladnými vlivy globálního kapitalismu a v posilování nového přeshraničního institucionálního a komunikačního rámce (tedy $\mathrm{v}$ demokratizaci EU). Souhlasím s autorem také $\mathrm{v}$ tom, že pokud by byl (globální) kapitalismus nesen tržním fundamentalismem (a on jím nesen je), ohrožovaly by jeho důsledky jak lidská práva (tedy liberalismus samý), tak demokratické vládnutí. Nevidím však východisko ve zdůrazňování přirozeného a transcendentního rámce obce jako cestu k ochraně lidské důstojnosti, svobody a rovnosti. Spíše bych se obával opaku.

Vláda práva a ústavní stát nevznikají přirozeně či spontánně revolučně, spíše musí být budovány pomocí pozitivního práva a musí být chráněny a rozvíjeny za historicky se měnících okolností [Habermas 2013: 30]. Vláda práva je v demokratických zemích posilována rovností, nenásilím a politickou stabilitou, právní kontinuitou a především existencí efektivního nezávislého soudnictví, nikoli revolučními zvraty či legislativní náruživostí. Zde je třeba připomenout, že i ČR je - při vědomí všech nedokonalostí - standardní demokracií, kde je třeba hledat př́ležitosti pro dílčí zlepšení $\mathrm{v}$ rámci ustaveného politického a právního řádu. Cestou k tomu je jak dưraz (shora) na institucionální inovace a reflexivitu politického systému, tak na posilování (zdola) politické gramotnosti a občanských kompetencí v rámci občanské společnosti. Hlavní nástroj zvládání globálního kapitalismu proto spatřuji také $\mathrm{v}$ osvětě a vzdělání, které by $\mathrm{u}$ dětí posilovalo občanské kompetence, a které by je vedlo k dovednostem smírrlivé (civil) sebe/prezentace, k autonomii (i odpovědnosti), ke kreativitě a zároveň také k respektu k druhým/ jiným a ke smyslu pro zájmovou a názorovou pluralitu. Součástí vzdělávacích programů musí být program demokratické politické socializace usilující nejen o toleranci, ale především o posilování smyslu pro zájmovou a názorovou pluralitu, ve které je možné také nalézat určité zalíbení. Pokud jde o českou společnost, xenofílie představuje hodnotovou orientaci - a v tom se ČR liší od mnohých západních zemí-, která je ve veřejné sféře velmi slabě re/prezentována (a v českých dějinách tomu nebylo jinak; viz Müller [2003]). Posilování xenofilních orientací však může zaručit pouze robustní veřejná sféra, jež si uchovává sekulární povahu a jež se bude opírat o množství institucionálních pojistek a opor (např. o výše diskutovanou aktivní hranici) i o morální přesvědčení většinové společnosti. Evropská veřejná sféra (či sféra evropských veřejností) by měla být zárukou civilizovaného střetávání s jinými, které může být snesitelně nepř́ijemné, stejně jako povznášející a vzájemně př́nosné.

Karel B. Müller 


\section{Literatura}

Alexander, J. 2006. The Civil Sphere. Oxford, NY: University Press.

Beck, U. 2010. A God of Ones's Own. Cambridge: Polity Press.

Delanty, G. 2011. „Cultural Diversity, Democracy and the Prospect of Cosmopolitanism:

A Theory of Cultural Encounters." The British Journal of Sociology 62: 633-656.

Eder, K. 2006. „Europe's Borders. The Narrative Construction of the Boundaries of Europe." European Journal of Social Theory 9 (2): 255-271.

Habermas, J. 2013. K ustavení Evropy. Praha: Filosofia.

Koopmans, R. 2007. „Who Inhabits the European Public Sphere? Winners and Losers, Supporters and Opponents in Europeanised Political Debate." European Journal of Political Research 43: 186-210.

Levinas, E. 1994. Etika a nekonečno. Praha: Oikoymenh.

March, A. 2013. „Rethinking Religious Reasons in Public Justification.“ American Political Science Review 107 (3): 523-539.

Müller, K. 2003. Češi a občanská společnost. Praha: Triton.

Müller, K. B. 2008. Evropa a občanská společnost. Projekt evropské identity. Praha: Sociologické nakladatelství (SLON).

Müller, K. B. 2012. „Veřejná sféra, identita a dilema politizace. Čtyři syntetické teze k evropeizaci občanské společnosti." Politologická revue 2: 120-136.

Müller, K. B. 2014. „Aktivní hranice a evropeizace veřejné sféry. Jak ,stejný‘ může být i ,jiný a naopak." Sociológia 46 (4): 412-433.

Risse, T. 2010. A Community of Europeans? Transnational Identities and Public Spheres. Ithaca, London: Cornell University Press.

Shils, E. 1975. Center and Periphery. Essays in Macro-Sociology. Chicago: Chicago University Press. 